УДК 340.143

DOI https: / / doi.org/10.32837/yuv.v0i6.2025

\author{
I. Невзоров, \\ кандидат юридичних наук, \\ професор кафедри теорії та історії держави і права \\ факультету № 1 \\ Харківського національного університету внутрішніх справ
}

\title{
ГЕНЕЗА ТА РОЗВИТОК УЯВЛЕНЬ ПРО ПРИРОДУ «ПРАВОВОЇ ФІКЦІї» У ВІТЧИЗНЯНІЙ ТА СВІТОВІЙ ЮРИСПРУДЕНЦІї
}

Постановка проблеми. Існування сучасної світової юриспруденції неможливе без активного використання такого прийому юридичної техніки як «правова (або юридична) фікція». Про це свідчать багаточисленні нормативно-правові акти та наукові дослідження більшості країн світу. Використання правової фікції в багатьох галузях права робить ii універсальним засобом подолання прогалин у законодавстві, слугує цілям вірного тлумачення нормативно-правових актів, створює підгрунтя для подальшого розвитку та вдосконалення наявних джерел права у кожній країні окремо та в міжнародних правових актах. Крім того, такий техніко-юридичний прийом «правова фікція» колись був широко розповсюджений у звичаєвому та релігійному праві.

Багаторічне обмеження в доступі до всесвітніх надбань юридичної думки за радянського періоду нашої історії створило небезпечні прогалини у вітчизняній юриспруденції. Спроби подолання цих прогалин в останні два десятиріччя незалежності нашої держави не вирішили увесь комплекс наявних проблем.

Тому дослідження правової фікціï $€$ актуальною потребою сучасної вітчизняної юридичної науки на шляху до взаємовигідного співробітництва 3 іншими країнами світу та приведення законодавства у відповідність до світових стандартів.
Стан наукової розробки проблеми. Дослідження природи фікцій у вітчизняній юридичній науці було розпочато із праці Д.І. Мейера «Про юридичні вигадки та припущення», опублікованій у 1853 р.

У 1895 році Г.Ф. Дормідонтов у своїй роботі «Класифікація явищ юридичного побуту, що відносяться до випадків вживання фікцій: Юридичні фікції і презумпції «повернув репутацію правовій фікції», охарактеризувавши жї у позитивному аспекті. Цей вчений наполягав на необхідності застосування фікції у законодавчій діяльності.

Крім того, питанням історії виникнення та розвитку правової фікції, як фундаментальному здобутку давньоримської правової думки, приділяли увагу в різні часи дослідники римського права, серед них: Д.Д. Гримм у праці «Лекції з догми римського права», I.A. Покровсбкий у своїй роботі «Історія Римського права», В.М. Яковлев у своєму дослідженні «Давньоримське приватне право та сучасне російське цивільне право», С.О. Муромцев у курсі «Цивільне право Давнього Риму», 1883 р. та інші.

Серед радянських вчених, які приділили увагу правовим фікціям у своїх працях, слід назвати Б.С. Утевського та його наукову роботу «Вина в радянському кримінальному праві. Курс кримінального права» 1950 р., дослідження B.К. Бабаєва «Презумпції в радянському 
праві» 1974 р., а також праці О.С. Іоффе, В.А. Мусіна «Основи римського права», 1975 р. та С.С Алексєєва «Загальна теорія права» 1982 р.

Радянська правова думка, грунтуючись на постулаті про те, що радянське право не може базуватися на вигадках, але його функціонування продиктоване лише фактами об'єктивної дійсності, використання правової фікції, як дієвого абстрактного інструменту юридичної техніки заперечувало за деякими виключеннями.

3 обранням Україною незалежності в юридичних наукових колах змінилося ставлення до багатьох явищ правової дійсності. Виник неабиякий інтерес до питань, пов'язаних із використанням правової фікції, з'ясування ії правової сутності, ознак, шляху розмежування з іншими спорідненими категоріями.

Серед робіт українських вчених, виданих на початку XX ст., слід згадати про навчальний посібник «Презумпції та фікції в податковому праві» I.I. Бабіна (2009 р.), де автор аналізує використання фікцій у вітчизняному податковому праві, співвідношення фікцій та презумпцій.

Крім того, дослідження поняття правової фікції знайшло своє відображення у статтях А.I. Іванського, зокрема «Роль юридичних фікцій у регулюванні відносин фінансово-правової відповідальності» (електронний ресурс). Та деяких інших авторів.

Класичною зарубіжною роботою $\mathrm{XX}$ сторіччя, присвяченою дослідженню фікцій, є праця професора Гарвардського університету Л. Фуллера «Юридичні фікції», де він детально вивчив їхню роль у праві. На його думку, фікція є ствердженням, яке проголошується із повним або частковим усвідомленням iі хибності; i, по-друге, вона несе у собі користь. Якщо одна із двох частин вказаного визначення ігнорується, то відповідне твердження перестає бути фікцією.

Також необхідно підкреслити, що у вітчизняній правовій науці питанням правової фікції у різні часи присвятили свої праці такі вчені: Д.І. Мейер, Г.С. Мен, Г.Ф. Шершеневич, B.I. Камінская, М.С. Строгович, П.Ф. Пашкевич, К.К. Панько, Д.М. Щекін та інші.

В Україні питанням розробки цієї проблематики у різних галузях юридичної науки приділяли увагу такі науковці, як: М.В. Цвік, В.Д. Ткаченко, О.М. Литвак, І.О. Биля, І.Г. Оборотов, I.I. Бабін та інші. Проте увага науковців до проведення всебічного дослідження правової фікції $є$ незначною. Це дає підстави стверджувати, що грунтовна розробка питань, пов'язаних із функціонуванням правової фікції, лише започатковується.

Метою статті є дослідження розвитку уявлень про категорію «правова фікція» у вітчизняній та світовій юриспруденції.

Викладення основного матеріалу. Генеза уявлень про «правову фікцію» сягає часів Давньо Римської імперії. Дослідники римського права вказують на те, що fictio $є$ витвором римських юристів. Fictio est contra veritatem, sed pro veritatae habetur (фікція протирічить істині, але фікція визнається за істину) [1, с. 48].

$\mathrm{y}$ давньому Римі з розвитком господарського обігу виникали нові майнові стосунки, для яких цивільне право не передбачало захисту. У таких випадках претор для надання судового захисту новому відношенню пропонував судді у формулі допустити існування фактів, яких насправді не було, тобто допустити фікцію і підвести під неї це нове відношення. Наприклад, коли в практику почала впроваджуватися така форма поступки права, як передача вимоги, претор писав у формулі судді: «Ти, суддя Октавій, допусти, що Авл Агерій є спадкоємцем Нумерія Негідія і у спадок отримав від нього право вимоги». Завдяки фікції особа, якій було передано право вимоги до іншої особи, отримувала позовний захист [2, с. 57].

Прийом фікції використовувався для вирішення спірних питань у багатьох сферах правовідносин. 


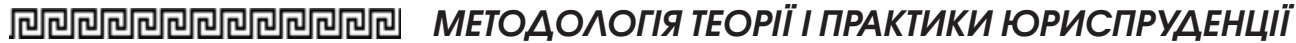

На думку більшості дослідників римського права, під фікцією у давньоримському праві розуміли: «fictio (fingere, ліпити, створювати: створювати видимість) уявне додавання ненаявного або неприйняття до уваги наявної обставини в межах певних юридичних категорій. Це спеціальний технічний засіб, який особливо часто використовується у процесуальних формулах (formula fictia: actio Publiciana) для отримання нових правових наслідків. Сприяло удосконаленню давньоримського права. Фікція завжди неспростовна на відміну від презумпції» [3, с. 130].

Хронологічні рамки найбільшої преторської активності, преторської правотворчості - 250-80 р. до н. э. У пошуках справедливого врегулювання майнових суперечок претори стали в багатьох випадках прибігати до юридичних фікцій. Деякі з них проникли в преторські формули. Суть фікції полягала в додаванні свідомо ненаявного факту або, навпаки, у відході від врахування яких-небудь, самих по собі безперечних, обставин. Будучи неспростовною у принципі, юридична фікція стала важливим знаряддям нової правотворчої думки. При зовнішній повазі до старого права, права Таблиць, претор насправді творив нове право, яке, за словами римського юриста Марціана, зробилося «живим голосом» цивільного права, ефективним засобом задоволення нових життєвих інтересів, що виникли із зростанням виробництва, торгівлі, поширенням товарних відношень взагалі [4, с. 9].

Матеріальною основою усіх преторських позовів, було вже не будьяке право позивача на те, щоб відповідач йому що-небудь заплатив, а просто відомий фактичний стан справ, сукупність відомих фактичних обставин, які роблять справедливим, щоб відповідач заплатив. Тому преторські позови спиралися завжди на деякий «factum», а їх формули були «formulae in factum conceptae». Най- частіше претор просто перераховував ці факти: якщо виявиться певний факт, відповідача звинуватять; тоді ми маємо «conceptio in factum просто». Але іноді справа могла бути спрощена: претор міг удатися до фікціï (фікція не підлягає запереченню і застосовується в позовних формулах для того, щоб пов'язати 3 ними нові правові наслідки), і тоді ми б мали formula ficticia. Наприклад, у відомих випадках особа могла втратити свою цивільну правоздатність, піддатися так званому сapitis deminutio; тоді воно зникало зі списку суб'єктів цивільного права, втрачало права, але звільнялося і від обов'язків. Остання обставина була несправедлива по відношенню до його кредиторів, і ось претор став давати їм позов з фікцією «ac si capite deminutus non esset», тобто судді пропонувалося у формулі судити так, ніби нічого в цьому сенсі не сталося». Фікція - в юридичному сенсі це уявне додавання ненаявного або неприйняття до уваги наявної обставини в рамках певних юридичних категорій [5, с. 127].

У випадках захоплення римського громадянина в полон не виключено було його повернення, а отже, і відновлення правосуб'єктності завдяки jus postliminii. Зважаючи на цю можливість майно римлянина, що знаходився в полоні, нікому не передавалося, а ввірялося опікунові, зобов'язаному стежити за його збереженням і повернути його власникові, як тільки той знову набуде свободи. Якщо ж полонений римлянин помирав, залишаючись рабом, то його майно переходило до спадкоємців. Оскільки раб, суворо кажучи, не міг а ні мати своїх прав, а ні, відповідно, передавати ї у спадок, - в подібних випадках було прийнято виходити з фіктивного припущення про те, що, розлучаючись зі свободою, воїн одночасно розлучився і з життям - «quasi tune decessive videtur, cum capitus est» (вважається таким, що якби помер той, хто полонений). За допомогою 
цієї фікції смерть «фактично настала, можливо, довгий час опісля» штучно приурочувалася до моменту, коли римлянин був ще вільною людиною, після якої, можливе спадкоємство. Для преторського захисту майнових придбань, котрі не знаходили прямого підтвердження в законі, використовувався закон, що спирався на такий специфічний юридичний прийом, як фікція. Претор користувався тим, що цивільне право знало набувальну давність (usucapio) - інститут, згідно 3 яким річ, навіть придбана 3 якими-небудь юридичними дефектами (наприклад, поза манципацією), ставала власністю набувача, що проволодів нею впродовж певного часу. I в усіх випадках, коли претор стикався з реальним придбанням майна, що відступало від деяких строгих вимог квіритського права, він застосовував до такого придбання фікцію закінчення терміну набувальної давності, що і дозволяло йому визнати набувача власником [6, с. 71-72].

У процесі вирішення конкретного життєвого випадку, якщо життєва ситуація не підпадає під наявні юридичні конструкції, римські юристи, на відміну від преторів, не могли самостійно використовувати такий технічний засіб, як фікція. Зарубіжні вчені пояснюють це тим, що юристи, не відступаючи від законів логіки (а фікція як корекція конкретної ситуації з метою врегулювання іï порушує закони логіки та ігнорує юридичну реальність), діючи шляхом інтерпретаціі, створювали нове право за допомогою аналогії (тобто шляхом розширювального тлумачення або уподібнень). Фікція, яка вводилася актом влади, відповідно, не могла впроваджуватися в правову практику шляхом інтерпретаціі. Тому, бажаючи ввести ту чи іншу фікцію, юристи зверталися до претора чи законодавця, використовуючи свій авторитет [7, с. 124].

Стисло формулюючи досягнення римських юристів із приводу фікції,
В.M. Яковлев наголошує на тому, що вони збагатили юриспруденцію оригінальним позовом, який через століття знайшов «притулок» у сучасному праві, у тому числі українському та російському. Йдеться про позови $з$ фікцією, фіктивних позовах (actiones ficticiae).

Фікції преторського права є неспростовними. Вони створювали в преторській юстиції нові правові наслідки. Створення фікцій було підпорядковано принципу справедливості в праві, тому з їх допомогою, при дотриманні інших законних умов, оформлювалося неформальне спадкоємство.

Прикладом рецепції у сучасному цивільному праві римського позову 3 фікцією $€$ інститут визнання громадянами безвісно відсутнім і об'явлення громадянина померлим [8, с. 71].

До середини XVIII століття юриспруденція знаходилася під тиском авторитету римського і канонічного права, та загальні ідеї були частиною традиційного спадку, оскільки природне право було закріплене в канонічному праві. У XVIII столітті природне право під впливом раціоналізму як філософської течії, перетворюється в раціональне право. Таким чином, до першої третини XIX століття теорія природного права складає суттєву частину європейської філософії держави і права та в епоху просвіти має вирішальний вплив на загальний розвиток права і держави. В епоху філософії відбувається відмова від традиціоналізму заради абстрактних правових ідей [9, с. 110].

Процес рецепції римського права у середньовічній Західній Європі супроводжується економічним розвитком. Римське право, поширюване вченими юристами - глосаторами i коментаторами - 3 кафедр, проникало в життя, і це сприйняття римського права Західною Європою носить назву рецепції римського права. Проте ця рецепція здійснилася в різних частинах Європи не однаковою мірою і не однаковими шляхами.

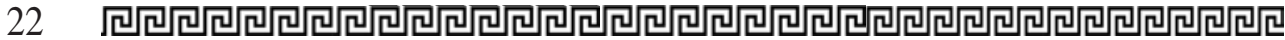




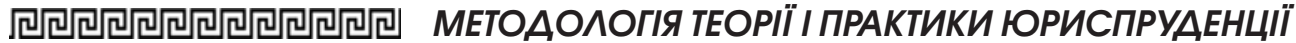

Безперервно зростав вплив римського права в країнах романських (Італія, Іспанія, Південна Франція). Зокрема, в Італії вже в XI столітті школою лангобардського права у Павії було проголошено, що римське право $€$ «lex generalis omnium» i що воно в усіх випадках може бути джерелом для заповнення місцевого права. Так само в Іспанії, римське право не втратило свого наповнювального значення: його положення проводилися тут на тій основі, що aequitas $€$ загальне субсидіарне джерело права, а положення римського права витікають, на думку іспанських юристів, з самої aequitas. Цим пояснюється відмічене вище величезне практичне значення коментарів Бартола в іспанських судах. Ще більше значення мало римське право у Франції: південна частина іï - рауs de droit йcrit - була цілком підпорядкована йому. Під впливом глосаторів мало-помалу в судовій «практиці замінюється Corpus Juris Civilis» Юстиніана. Проте і північна Франція pays de droit coutumier - далеко не залишилася в стороні від римського впливу. Вже дуже рано там виникло викладання римського права, причому центром його був університет в Орлеані: тут, з усіх міркувань, був складений і згаданий вище «Brachylogus» у кінці XI або початку XII століття. Згодом до Орлеанського університету приєднався Паризький. Римське право чинить дію на місцеві звичаї: ця дія позначається, наприклад, навіть на відомій старій збірці звичайного права «Coutume de Beauvaisis», складеному Бомануаром в другій половині XIII століття. Чим далі, тим цей вплив робиться сильніше. Згодом різка різниця між Францією південною і північною стирається, національне право і римське переробляються в одну правову систему, яка і знаходить собі потім вираження в Кодексі Наполеона 1804 роки.

Не чужий був вплив римського права і Англіі. У XII столітті тут виникло викладання римського права, поставлене глосатором Вакарием (Vacarius). У XIII столітті швидко зростаючий вплив римського права викликав сильну опозицію, в особливості з боку місцевої знаті; проте, викладання його не припинялося. Навчання римського права відбилися на відомих юридичних трактатах Гленвилля i Брактона, що мали велике значення в судах. Але феодальний лад в Англії був сильніший, ніж в інших країнах; він сходив зі сцени повільніше, і це накладало свій відбиток на усю історію країни. Внаслідок цього вплив римського права в подальшому розвитку англійського права не мав такого значення, як на континенті. Абсолютно особливого характеру набула рецепція римського права в Німеччині. Окрім загальних причин, що викликали поширення римського права скрізь, в Німеччині рецепції його сприяла ще і та обставина, що так звана Священна Римська імперія вважалася продовженням колишньої Римської імперії, а імператори першої безпосередніми наступниками імператорів останньої. Внаслідок цього Юстиніанівські Зведення схильні були вважати ніби вітчизняним кодексом, а 3 іншого боку, закони імператорів Священної Римської імперії додавали до Кодексів Юстініана, як його безпосереднє продовження. Фікція ця значно полегшувала дорогу римському праву в Німеччині; якщо скрізь королівська влада у своїй боротьбі з феодалізмом намагалася послатися на римське право і легістів, то германські імператори робили йому особливе заступництво: вище було згадано про привілеї, дані Фрідріхом I Болонському університету. Значною мірою в цьому тяжінні до римського права відігравала роль та ідея єдиного загальноімперського права, ідея національного об'єднання Німеччини, що здійснилася лише в XIX столітті [5, с. 268-270].

В англійському праві, після того як протягом XIII сторіччя і першій половині XIV, процесуальна система 
судових наказів і матеріальне загальне право досягли свого повного розвитку, мав місце процес аналогічний давньоримському праву, одним із основних принципів наслідування за строгим правом якого була агнатична родинність, тобто відношення, яке мало підставою або кровну родинність за чоловічою лінією, або штучне прийняття в родину згідно із приписаними юридичними формами. Звичайними спадкоємцями майна були так звані «власні спадкоємці», тобто члени родини, що знаходилися під безпосередньою «владою» батька. У випадку смерті без заповіту ці «власні спадкоємці» перші мали право на спадковість; наступне місце після них займав найближчий агнат покійного. Суворе використання цих правил тягло за собою суттєвий збиток для осіб, за якими почали визнавати природне право на участь у майні покійного. Тому претор зменшив суворість цих норм, застосовуючи принципи јus gentium. Він досяг цього шляхом доктрини «володіння майном» (bonorum posessio). Він не ігнорував та не відміняв норм суворого права, не знищував формального права спадкоємця; проте за допомогою фікцій і сумарних засобів судового захисту він ставив «у положення спадкоємця» особу, за якою визнавав природне домагання. У випадку смерті без заповіту претор доповнював принцип агнатичної родинності більш широким принципом когнатичної родинності, тобто кровної родинності у сучасному розумінні цього слова, яке включало і родинність за жіночою лінією. Перш за все, перевага надавалася законним дітям покійного; по-друге, тим, чиї права встановлювалися нормами спадкоємства за суворим правом, у третіх, найближчим родичам по крові, і в-четвертих, удові чи вдівцю покійної особи [10, с. 172].

«Тільки частина цивільного права Німеччини є місцевого походження, інша - більша його частина має підставою інші запозичення, перш за все римське» та «римське право стало чинним у Німеччині не внаслідок законодавчого акту, а подібно звичаєвому праву, через дотримання його не народом, а юристами», - вказував наприкінці XIX століття німецький вчений Віндшейд $[11$, с. 1, 2].

Таким чином, із рецепцією давньоримського права протягом століть у західноєвропейських країнах, а згодом і у вітчизняній науці питанням дослідження фікції у давньоримському праві приділяла увагу величезна кількість вчених. Цитування всіх у нашому дослідженні не уявляється можливим, оскільки вчені розбирали одні й ті ж самі сфери та випадки застосування фікції у давньоримському праві, роблячи окремі уточнення. Інтерес до цієї проблематики зберігається і в наш час. Розвиток суспільних правовідносин у світі вимагає пошуку нових механізмів удосконалення ї законодавчого врегулювання на базі вже наявного людського надбання у юридичній науці.

Як вірно вказує сучасний дослідник правової фікції в давньоримському праві А.М. Ширвіндт, «сучасні теорії юридичної фікції витікають у своїй більшості з досліджень XIX століття, котрі концентрувалися, головним чином, на дослідженні римського досвіду. Єдність висновків історіографічної традиції носить суб'єктивний характер, проте допомагає інтерпретувати дані римських джерел». Також автор вказує, що «питання про значення фікції не отримало задовільної відповіді у дослідників римського права минулого» і сучасності [12, с. 4].

У межах вищесказаного не згасає інтерес до праць вітчизняних вчених минулого.

Так, видатний цивіліст Д.І. Мейер вперше в науці цивільного права Російської імперії у своїй праці «Про юридичні вигадки і припущення, прихованих і удаваних діях» дослідив та проаналізував роботи давньоримських юристів із приводу правової фікціі. Він, зокрема, відносив правову 


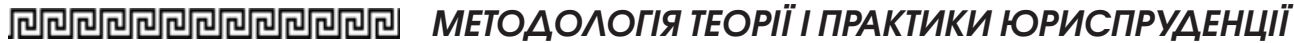

фікцію до девіацій від нормального порядку: визначень, розрахованих на відомі факти, що отримують силу, за відсутності останніх. До них належать: вигадки (фікціï), припущення (презумпціі), конклюдентні (приховані) дії та симуляції (удавані дії). У рамках цієї категорії Д.І. Мейер дає визначення поняття вигадки (фікціi) у давньоримському праві: «Вигадане існування факту, про який відомо, що він зовсім не існує або існує в іншому вигляді. До них належать так звані вигадки права fictiones juris». Далі автор аналізує праці давньоримських юристів - Гая та Ульпіана, щодо поняття юридичної вигадки (фікціі): «Іноземець за вигадкою приймається за римського громадянина, коли $є$ позивачем чи відповідачем за позовом, встановленим між римськими громадянами». Підсумовуючі свій аналіз, автор вказував, що «влада використовує вигадку: не жертвуючи формалізмом, вона задовольняє умовам життя і поряд з тим вірна духу часу». Він робить висновок про те, що вигадка $є$ підставою розповсюдження будь-якого правила на випадок, який підходить під інше правило, та що в римському праві поняття про вигадку було спершу відповідне духу того права, знаряддям узагальнення юридичних правил, тому характер вигадки виключно історичний, який прихований під допущеним романістами недоречним додатком вигадки до всілякого узагальнення до надання абстрактним юридичних понять у форму, доступну уявленню, як найбільш наближену чуттєвому сприйняттю. Тому автор не визнає законність запозичення юридичної вигадки як загальнолюдського надбання у будь-якому юридичному побуті, а також вважає це явище чуже сучасному йому праву, незважаючи на те, що воно розповсюджує іноді визначення, за якими обговорюються відомі факти, на інші їм протилежні, та використовуються у нас звороти і вирази, подібні до тих, які спонукали романістів без необхідності вигадувати вигадки $[13$, с. 2,4 , 5, 30, 31].

На протилежність йому Г.Ф. Дормідонтов у своїй праці «Класифікація явищ юридичного побуту, відносно випадків застосування фікцій» вказав та визначив категорії явищ застосування фікцій у праві, а також їх ознаки. Він вбачав ширше коло явищ застосування фікцій, ніж це було визначено Д.І. Мейером, та дещо по-іншому вбачає сутність вказаного явища. Також Г.Ф. Дормідонтов пише, що «у всій європейській літературі (на момент написання роботи) не налічується десяти творів, спеціально присвячених розробці питання щодо юридичних фікцій взагалі, їх видам, причинам їх виникнення, ролі ix у минулому та сучасному (автору) житті людства.» Стосовно значення, поняття, класифікацій явищ юридичного побуту, у яких застосовуються юридичні фікції та відмежуваннях їх від презумпцій, вчений зазначав, що фікція є відомим прийомом мислення, який складається 3 допущення наявною відомої ненаявної обставини, або навпаки, ненаявним наявного, у вирішенні завдання за допомогою хибного положення; а юридична фікція в тісному сенсі - той самий прийом, але який допускається об'єктивним правом у відомих випадках. Припущення взагалі (презумпція) - обрана чи прийнята думка про сумнівний предмет. Припущення загальнолюдське така думка, яку за тими чи іншими підставами можна назвати загальновизнаною, пануючою у середовищі мислячих людей. Під юридичним припущенням у широкому сенсі - будьяке визначення об'єктивного права, в якому виражається прийняття законодавцем визначеної думки відносно будь-якого сумнівного предмету. Під юридичним припущенням у технічному сенсі розуміють юридичне визначення, в силу якого можливий, але сумнівний факт чи певна якість приймаються за об’єктивно вірогідні або 
навіть достовірні і обговорюються як наявні і доведені. Цей прийом родовий до прийому створення фікцій. Різниця між фікціями та презумпціями полягає в тому, що за фікцією приписується вигадувати відомий факт чи якість, заздалегідь не наявну, а за презумпцією - приймати відомий можливий, але сумнівний факт чи таку якість за доведену. Припущення виражене у правилі «Незнання закону не звільняє від відповідальності та в більшості випадків прямо співпадає з вигадкою. Існує родовий зв'язок між презумпцією та фікцією. Автор заперечує думку про те, що презумпція - плід розуму, а фікція - уявлення. Він доводить це на прикладі визнання юридичної особи та правоздатності у майновій сфері за державою, спільнотами і корпораціями. Можливі випадки, коли воля особи на певну дію чи на досягнення певні юридичних наслідків виражається посередньо в іншій дії, яка має свою самостійну ціль. При цьому воля може віднайтися з переконливістю, ясністю, оскільки факт, що іï знаходить, уявляється доказуваним, чи цей факт може обгрунтовувати тільки законне припущення на користь буття волі. У цих випадках можна казати про конклюдентні факти (приховані діi). Також він розмежовує поняття про юридичну фікцію та символ, символічну дію: фікція - прийом юридичного мислення, напроти, символ та символічна дія - лише зовнішній образ вираження юридичної дії чи відношення. Фікція з'являється тоді, коли зображуваного зовсім немає, а на особу - один образ, символ, завдяки якому зображуване обговорюється як наявне. Вчений аналізує встановлені Д.І. Мейером категорії удаваних правочинів: а) в обхід закону; б) на шкоду правам сторонніх осіб; в) для обману сторонніх осіб 3 ганебною метою; г) без ганебної мети. Тобто немає підстави уживати фікцію у широкому сенсі, лише у вузькому сенсі [14].

Також слід відзначити С.О. Муромцева, який вважав фікції невдоско- наленим логічним прийомом, який був викликаний відомими історичними умовами, проте його не можна розповсюджувати далі, ніж встановлено історією» [16].

$\mathrm{y}$ радянський період дослідження цього питання було майже відсутнє, за винятком окремих згадок у дослідженнях В.А. Ойгензихта, В.I. Камінської, В.Б. Ісакова, О.С. Іоффе, А. Нашиць, B.I. Бабаєва та деяких інших.

Причиною подібного «зневажання» правової фікції, мабуть, слід шукати у протиставленні радянського права і права капіталістичних країн. Невипадково в тогочасній літературі вказувалося про те, що філософською базою оцінюваних теорій у буржуазному кримінальному праві $є$ кантіанська філософія, а політичною базою - реакція, яка є неминучою ознакою імперіалізму, політичною базою радянських оцінюваних теорій є інтереси соціалістичної держави в його боротьбі з усіма діями, що перешкоджають виконанню завдань поступового переходу від соціалізму до комунізму, а їхньою філософською базою - ленінське вчення про партійність у філософіï, в науці та у практиці соціалістичного будування. Нормативні неокантіанські «теорії» зводять «оцінку» до зовсім вільного, незалежного від доведених фактичних обставин, тобто від об'єктивної реальності, думки суддів про наявність чи відсутність у підсудного умислу чи необережності перетворюється у нічого не значущу фікцію», «...для того, щоб не стільки обгрунтувати кримінальну відповідальність за необережність взагалі (а значить i за злочинну недбалість), скільки приховати дійсну природу необережності, буржуазні криміналісти створювали різноманітні фікції, пропонували нежиттєві, штучні юридичні концепції» $[15$, с. 214,217$]$. Тобто фікція (вигадка) не могла бути використаною, оскільки радянське право грунтується на фактах реально наявної дійсності. А все хибне, вигадане притаманно лише 


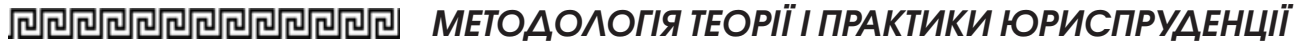

капіталістичній юриспруденції. Цим підкреслюється антилюдяний характер капіталістичного способу життя. Тобто фікція стала своєрідним знаряддям боротьби та протиставлення між двома світовими світоглядними системами.

У цьому руслі В.А. Ойгензіхт вказував, що фікція свідомо неістинне положення приймає за істинне та є чисто практичним прийомом, простою нормою права, яка встановлює певний порядок правовідносин. У буржуазному праві фікції використовуються для класового маскування». Автор не вбачає у фікції засіб подолання прогалин у законодавстві, відводячи цю роль презумпції [16, с. 14, 15].

На думку Б.С. Антимонова та К.А. Грабе, юридична фікція «посмертного продовження влади» власника, що помер, за допомогою норм спадкового права - зовсім не результат творчості правознавців. Вони роблять висновок про те, що наш закон фікцій навіть неспростовних презумпцій не встановлює [17].

Хоча деякі вчені припускали застосування правових фікцій в окремих випадках, як загально правовий метод.

Німецький вчений Й.А. Шумпетер зазначав, що «там, де закінчується один раз встановлений порядок, більшість зупиняються, інші діють зовсім по-різному. Допущення поведінки, котре спостерігач може зрозуміти точним і раціональним в будь якому випадку є фікцією, але вона виправдана, навіть якщо події відбуваються досить повільно щоб люди встигли зрозуміти їх логіку» [18, с. 176].

У США до першої світової війни правова фікція досить часто дискредитувала судову систему завдяки недосконалості судового захисту та розквіту злочинності у цей період [19, с. 110]. Згодом, із розширенням товарообігу та вдосконаленням нормативно-правової бази, юридична фiкція відіграє помітну роль у законотворчій діяльності цієї держави.
Сучасному Ізраїлю також притаманне застосування правових фікцій у різноманітних правовідносинах. Так, єврейські громади мають товариства гемилут хесед (безвідсоткових позик), де бідні можуть отримати безвідсотковий кредит. Тора забороняє євреям стягувати відсоток за позиками єврея. У біблійну епоху життя євреїв в основному зводилося до сільського господарства, і потреба в грошах виникала украй рідко. 3 розвитком економіки гроші стали розглядатися як будь-яке інше майно - і люди більше не хотіли давати у борг, якщо не чекали за це плати. У результаті була створена правова фікція, яка все ще використовується ортодоксами. Кредитор стає партнером у справі позичальника і отримує плату за кредит(яка перевищує первинну суму) як свою долю у бізнесі. Але на відміну від справжнього партнера, йому треба заплатити, навіть якщо справа не приносить прибутку. Правова фікція, відома в єврейському праві як гетер іцка, «дозвіл на бізнес», дозволяється тільки при наданні кредиту заможним людям. Під час дачі грошей бідним єврейське право забороняє відсотки у будь-якій формі [20, с. 250].

Фікції як засіб юридичної техніки активно використовується у всьому світі. Як ми вже згадували, юридичні фікції з'явилися у сучасній світовій юриспруденції завдяки рецепції давньоримського права, яка тривала довгі роки. Із розширенням впливу права європейських країн фікція дедалі отримувала розповсюдження та світове визнання як ефективний прийом подолання відставань права від реалій життя. Фікція активно застосовується у міжнародних нормативноправових актах. Зокрема, B UNCITRAL: United Nations Commission on International Trade Law Yearbook 2003 міститься вказівка на те, що «Монреальська конвенція не вносить суттєвих змін до системи, встановленої Варшавською конвенцією: формулювання статей 1.1. і 1.2. 
ідентичні, а стаття Варшавської конвенції стала статтею 38.1 Монреальської конвенції. Новим положенням, проте, є юридична фікція, згідно 3 якою санкціонується практика, що склалася в цей час, принаймні в Європі, коли значна частина повітряних перевезень вантажів фактично здійснюється автомобільним транспортом. У статті 18.4 передбачається, що таке перевезення, здійснене без згоди вантажовідправника, вважається здійсненою у строк повітряного перевезення» [21].

Висновок. Відстеження генези та розвитку уявлень про природу правової фікції у вітчизняній та світовій юриспруденції вказує на те, що фікція $є$ відомим прийомом мислення, який складається в допущенні наявною відомої ненаявної обставини, або навпаки, ненаявним наявного, у вирішенні завдання за допомогою хибного положення; а юридична фікція в тісному сенсі - той самий прийом, але який допускається об'єктивним правом у відомих випадках. Своєю чергою, потреба у аї існуванні зумовлюється необхідністю:

1) захисту визнаних справедливими вимог із боку неповноправних осіб (наприклад іноземців), які шляхом фіктивного допущення дорівнювалися повноправним римським громадянам і тим самим могли повноцінно заявити про свої права;

2) захисту вимог, що витікають 3 нових ситуацій, не передбачених попередніми процедурами. У цьому випадку урочисті формули, якими надавалося право на позов, видозмінювалися стосовно нових обставин;

3) захисту вимог, що визнаються лише на підставі преторського права i не втілюваних раніше в позовах в межах традиційних правових норм.

Aктуальність статті полягає в тому, що існування сучасної світової юриспруденції неможливе без активного використання такого прийому юридичної техніки як «правова (або юридична) фікиія». Про иее свідчать багаточисленні нормативно-правові акти та наукові дослідження більшості країн світу. Використання правової фікиї в багатьох галузях права робить ї універсальним засобом подолання прогалин у законодавстві, слугуе ицілям вірного тлумачення нормативно-правових актів, створює підгрунтя для подальшого розвитку та вдосконалення наявних джерел права в кожній країні окремо та в міннародних правових актах. Крім того, такий техніко-юридичний прийом «правова фікиія» колись був широко розповсюджений у звичаєвому та релігійному праві. Визначено, що фікиіі як засіб юридичної техніки активно використовується у всьому світі. Як ми вже згадували, юридичні фікиії з'явилися у сучасній світовій юриспруденціï завдяки рец̧епціiі давньоримського права, яка тривала довгі роки. Із розширенням впливу права європейських країн фікиія дедалі отримувала розповсюдження та світове визнання як ефективний прийом подолання відставань права від реалій життя. Фікція активно застосовуеться в міжнародних нормативно-правових актах. Фікиія є відомим прийомом мислення, який складається в допущенні наявною відомої ненаявної обставини, або навпаки, ненаявним наявного, у вирішенні завдання за допомогою хибного положення; а юридична фікція в тісному сенсі - той самий прийом, але який допускається об'єктивним правом у відомих випадках. Своєю чергою, потреба у ї існуванні зумовлюеться необхідністю: а) захисту визнаних справедливими вимог із боку неповноправних осіб (наприклад, іноземців), які шляхом фіктивного допущення дорівнювалися до повноправних римських громадян $i$ тим самим могли повноцінно заявити про свої права; б) захисту вимог, 
що витікають із нових ситуацій, не передбачених попередніми процедурами. У изолу випадку урочисті формули, якими надавалося право на позов, видозмінювалися стосовно нових обставин; в) захисту вимог, що визнаються лище на підставі преторського права $i$ не втілюваних раніше в позовах у менах традиційних правових норм.

Ключові слова: правова фікція, нормотворчість, презумпція, прийоми юридичної техніки, юридичні факти, правовідносини, справедливість у праві, істина у праві.

\section{Nevzorov I. Origin and development of ideas about} the nature of legal fiction in domestic and global jurisprudence

The relevance of the article is that the existence of modern world jurisprudence is impossible without the active use of such a technique of legal technique as "legal (or legal) fiction". This is evidenced by numerous regulations and scientific studies in most countries. The use of legal fiction in many areas of law makes it a universal means of overcoming gaps in the law, serves the purpose of correct interpretation of regulations, creates a basis for further development and improvement of existing sources of law in each country separately and in international law. In addition, such a technical and legal technique of "legal fiction" was once widespread in customary and religious law. It is determined that fiction as a means of legal technique is actively used around the world. As we have already mentioned, legal fictions appeared in modern world jurisprudence due to the reception of ancient Roman law, which lasted for many years. With the growing influence of European law, fiction has become more widespread and recognized worldwide as an effective way to overcome the gap between law and the realities of life. Fiction is actively used in international regulations. It is made that fiction is a known method of thinking, which consists in the assumption of an existing known non-existent circumstance, or, conversely, non-existent existing, in solving a problem with the help of a wrong position; and legal fiction in the narrow sense is the same technique, but which is allowed by objective law in certain cases. In turn, the need for its existence is conditioned by the need to: a) protect the recognized just claims of minors (such as foreigners), who by fictitious admission were equal to full Roman citizens and thus could fully assert their rights; b) protection of claims arising from new situations not provided for in previous procedures. In this case, the ceremonial formulas giving the right to sue were modified in relation to new circumstances; c) protection of claims recognized only on the basis of praetorian law and not previously embodied in lawsuits within the framework of traditional legal norms.

Key words: legal fiction, rulemaking, presumption, techniques of legal technique, legal facts, legal relations, justice in law, truth in law.

\section{Література}

1. Арямов А.А. Общая теория риска: юридический, экономический и психологический анализ : монография Москва : РАП; Волтерс Клувер, 2010. 208 с.

2. Подопригора А.А. Основы римского гражданского права: учеб. пособие. Киев : Вентури, 1995. 288 c.

3. Бартошек М. Римское право: понятия, терминь, определения / пер. с чешск. Москва: Юрид. Лит., 1989. 448 с.

4. Черниловский 3.М. Римское частное право: элементарный курс. Москва: Новый Юрист, 1997. 224 с.

5. Покровский И.А. История Римского права / пер. А. Рудоквас. Москва : Стаmym, 2004. $540 \mathrm{c}$.

6. Ноффе О.С., Мусин В.А. Основы римского гражданского права. Ленинград : Из-во Ленинградского ун-та. 1975. $156 \mathrm{c}$. 
7. Федущак-Заславська Г. Становлення $і$ розвиток правових конструкціи у давньому Римі. Вісник Львівського Університету. Серія юридичні науки. 2011. Bun. 52. C. 120-126.

8. Яковлев В.Н. Древнеримское частное право и современное российское гражданское право: учебник. Москва : Волтерс Клувер, 2010939 с.

9. Рябченко Н.Г. Проблемы естественного права в учениях неметких юристов : дис. ... канд. юрид. наук : 12.00.01. Санкт-Петербург, 2002. 210 с.

10. Виноградов П.Г. Очерки по теории права. Римское право в средневековой Eвpone / под ред. У.Э. Батлера, В.А. Томсинова. Москва: Зериало, 2010. 285 с.

11. Учебник пандектного права. Сочинение профессора Гейдельбергского университета Виндшейда. Том I. Общая часть. / под ред. С.В. Пахмана. Санкт-Петербург: Нздание А. Гиероглифова и И. Никифорова, 1874. 358 с.

12. Ширвиндт А.М. Значение фикиии в римском праве: автореф. дис. ... канд. юрид. наук : 12.00.01. Москва, 2011. 26 с.

13. Мейер Д.И. «О юридических вымыслах и предположениях, о скртыных и притворных действиях». Казань, 1854. 129 c.

14. Дормидонтов Г.Ф. Классификация явлений юридического быта, относимых к случаям применения фикиий: Юриди ческие фикици; Презумпции; Скрытые, символические, притворные и мниме действия; Фидуииарные сделки. Казань : Типо-литография Императорского Университета, 1895 г. 176 c.

15. Утевский Б.С. Вина в советском уголовном праве. Курс советского уголовного права. Всесоюзный інститут юридических наук Министерства юстиции СССР. Государственное издательство юридической литературы. Москва: 1950. 319 c.

16. Ойгензихт B.A. Презумпции в советском гражданском праве. Душанбе : Издательство «Ирфон», 1976. 190 с.

17. Антимонов Б.С., Граве К.А. Советское наследственное право. Москва: Юр.лит. 1955. 264 с.

18. Шумпетер Й.А. Теория экономического развития / пер. В.С. Автономова. Москва: Прогресс, 2008. 401 c.

19. The Many Legalities of Early America (Published by the Omohundro Institute of Early American Histo) First Trade Edition by Christopher L. Tomlins (Editor), Bruce H. Mann (Editor). 2001, 480 p.

20. Телушкин Й. Еврейский мир. Москва : Издательство «Мостьк кульmypы». 2009. 624 c.

21. United Nations,United Nations Commission on International Trade Law. Ежегодник ЮНСИТРАЛ. Том ХХХІV В: 2003 год. Комиссия Организации Объединенных наций по праву международног торговли. 904 с. 